\title{
EFEKTIVITAS GEL ANTIJERAWAT EKSTRAK METANOL DAUN PACAR AIR (Impatiens balsamina L.) TERHADAP BAKTERI Propionibacterium acnes dan Staphylococcus epidermidis SECARA IN VITRO
}

\author{
Septira Murtiningsih, Siti Nani Nurbaeti, Indri Kusharyanti \\ Program Studi Farmasi, Fakultas Kedokteran, Universitas Tanjungpura Pontianak
}

\begin{abstract}
Propionibacterium acnes dan Staphylococcus epidermidis is an inflamation triggering bacterias in acne vulgaris. Plants that has been studied for antibacterial effect is Impatiens balsamina. Gel bases for acnes therapy are hydrophilic bases like HPMC (Hydroxypropyl methylcellulose) and carbopol. The aim of this study was to know the optimum combination of Carbopol and HPMC (Hydroxypropyl metylcellulose) in gel formulation that gives best antibacterial effect and to evaluate physical and chemical properties of gel. Extraction was performed by soxhlet method with methanol as solvent. The design of optimum gel formulation was performed using simplex lattice design. Optimum gel formulation was combination of 21\% HPMC and 79\% Carbopol. Verification results showed that optimum gel of inhibition zone of $P$. acnes and S. epidermidis is $17.61 \pm 0.93$ $\mathrm{mm}$ and $16.01 \pm 1.01 \mathrm{~mm}$ respectively. Positive control compared to optimum gel showed inhibition zone toward P.acnes and S.epidermidis of $29.1 \pm 1.34 \mathrm{~mm}$ and $24.98 \pm 1.83 \mathrm{~mm}$ respectively. Analysis results using T-test showed that p-value was lower than 0.05 $(p<0.05)$ hence the effectivity from optimum gel was significantly different from positive control that has greater activity than optimum gel. Evaluation of optimum gel showed gel has dark brown color, specific odor from extract, adhesive force of 3.17 minutes, spreadibility of $32.69 \mathrm{~cm}^{2}$, viscosity of $436.66 \mathrm{cP}$ and as well as the $\mathrm{pH}$ of 5.23 .
\end{abstract}

Keywords: Methanolic extracts of Impatiens balsamina leaves, Propionibacterium acnes, Staphylococcus epidermidis, gel, carbopol, HPMC

\begin{abstract}
ABSTRAK
Propionibacterium acnes dan Staphylococcus epidermidis adalah bakteri pemicu peradangan pada jerawat. Tanaman yang telah banyak diteliti sebagai antibakteri adalah pacar air (Impatiens balsamina L.). Bahan dasar gel yang cocok untuk terapi jerawat adalah bahan dasar hidrofilik seperti HPMC (Hydroxypropyl methylcellulose) dan karbopol. Tujuan dari penelitian ini adalah untuk mengetahui kombinasi optimum HPMC dan karbopol yang dapat memberikan efek antibakteri yang baik dan mengetahui evaluasi sediaan gel optimum secara fisik dan kimia. Ekstraksi daun pacar air menggunakan metode sokletasi dengan pelarut metanol. Perancangan formula optimum gel ekstrak metanol daun pacar air menggunakan simplex lattice design. Formula gel optimum adalah kombinasi HPMC $21 \%$ dan Karbopol $79 \%$. Hasil verifikasi menunjukkan bahwa diameter zona hambat yang dihasilkan gel optimum berada dalam rentang yang diprediksi terhadap

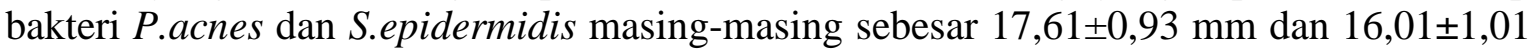
$\mathrm{mm}$. Kontrol positif setelah dibandingkan dengan gel optimum menghasilkan diameter zona hambat terhadap P.acnes dan S.epidermidis masing-masing sebesar 29,1 $\pm 1,34 \mathrm{~mm}$ dan 24,98 $\pm 1,83 \mathrm{~mm}$. Hasil analisa uji $\mathrm{T}$ menunjukkan nilai $(\mathrm{p}<0,05)$ maka efektivitas gel optimum berbeda signifikan dengan kontrol positif dimana efektivitas kontrol positif lebih besar daripada gel optimum. Hasil evaluasi gel optimum yaitu gel berwarna coklat tua,
\end{abstract}


berbau khas ekstrak dengan nilai daya lekat 3,17 menit, daya sebar $32,69 \mathrm{~cm}^{2}$ dan viskositas sebesar 426,66 cP serta nilai $\mathrm{pH}$ sebesar 5,23 yang memenuhi syarat.

Kata kunci: Ekstrak metanol daun pacar air, Propionibacterium acnes, Staphylococcus epidermidis, gel, karbopol, HPMC

\section{PENDAHULUAN}

Penyakit kulit yang sering timbul dan mengganggu para remaja adalah jerawat atau acne vulgaris (Knutsen-Larson Siri, dkk., 2012). Prevalensi jerawat pada masa remaja cukup tinggi, yaitu berkisar antara 47-90\%. Penyakit ini tidak mengancam jiwa, namun merugikan karena berhubungan dengan menurunnya kepercayaan diri akibat berkurangnya keindahan wajah para penderita. Jerawat juga dapat mempengaruhi kualitas hidup penderita jerawat dengan memberikan efek psikologis yang buruk. Penelitian di Yunani melaporkan dari 1531 sampel remaja berusia 11 sampai 19 tahun yang menderita jerawat dan yang tidak menderita jerawat, secara signifikan tingkat keparahan jerawat mempengaruhi quality of life (QOL). Pasien dengan tingkat keparahan jerawat yang tinggi mengalami gangguan psikososial dan emosional yang lebih besar (Tasoula Eleni, dkk., 2012). Penyakit jerawat terbatas pada folikel polisebacea kepala dan badan bagian atas karena kelenjar sebacea di wilayah ini sangat aktif (Webster, 2002). Jerawat dapat terjadi karena penyumbatan pada pilosebaseus dan peradangan yang dipicu oleh bakteri Propionibacterium acnes dan Staphylococcus epidermidis (Wasitaatmadja, 2002).

Salah satu tanaman yang digunakan sebagai antibakteri adalah pacar air (Impatiens balsamina L.). Secara empiris tanaman pacar air memiliki banyak manfaat dari bagiannya yang dapat digunakan sebagai obat diantaranya untuk mengatasi terlambat haid, radang kulit bernanah, bisul dan radang pinggir kuku (Dalimartha, 2003). Selain itu, tanaman pacar air mengandung senyawa naftakuinon, kaempferol dan kuersetin yang diisolasi dari daun pacar air memiliki aktivitas antibakteri (Adfa M. 2007, dan Lim Young-Hee, dkk., 2007).

Sediaan dalam bentuk gel banyak digunakan karena mudah mengering, membentuk lapisan film yang mudah dicuci dan tidak mengandung minyak sehingga mengurangi resiko timbulnya peradangan lebih lanjut akibat akumulasi minyak pada pori-pori. Bentuk sediaan gel cocok untuk terapi topikal pada jerawat terutama penderita dengan tipe kulit berminyak (Russel, 2000), sehingga lebih cocok untuk digunakan oleh masyarakat Indonesia yang beriklim tropis dan mayoritas memiliki kulit berminyak. Bahan dasar gel yang cocok untuk terapi jerawat adalah bahan dasar yang larut dalam air (hidrofilik) dan bersifat memperlambat proses pengeringan sehingga mampu bertahan lama pada permukaan kulit (Bakker, dkk., 1990). Basis gel yang bersifat hidrofilik seperti HPMC dan karbopol dapat dikombinasikan dalam formulasi gel (Baviskar, dkk., 2013). Kombinasi HPMC dan carbopol dapat menghasilkan homogenitas gel yang baik serta mampu meningkatkan difusi obat (Quinones dan Ghaly, 2008).

Berdasarkan uraian tersebut, maka perlu dilakukan pengujian efektivitas antijerawat dengan kombinasi basis gel yaitu HPMC dan karbopol dari ekstrak metanol daun pacar air terhadap bakteri penyebab jerawat yaitu Propionibacterium acnes dan Staphylococcus epidermidis.

\section{METODE PENELITIAN}

Alat

Alat-alat yang digunakan dalam penelitian ini adalah: soxhlet apparatus, timbangan analitik (Precisa tipe 3209410-003), waterbath (Memmert tipe 
WNB-14), blender simplisia, vacuum rotary evaporator (Heldolph tipe Basis Hei-VAP Value), alat-alat gelas, mikropipet, hot plate (SCHOTT tipe D55122 Mainz), krus porselen, laminar air flow cabinet, autoklaf (HL tipe 36Ae), object glass, cover glass, kaca arloji, mantel pemanas (Toshniwal tipe HM. 0500), pH meter (Horiba tipe D-51), oven (Memmert Beschickung-Loading Model 100-800), desikator, cawan penguap, mortir, stamper, jarum ose, inkubator, lampu Bunsen, cawan petri, dan jangka sorong.

\section{Bahan:}

Bahan-bahan yang digunakan dalam penelitian ini meliputi bahan tumbuhan, bahan kimia dan bakteri uji. Bahan tumbuhan yang digunakan adalah simplisia daun pacar air (Impatiens balsamina L.). Bahan kimia yang digunakan meliputi bahan kualitas teknis dan pro analisis. Bahan kualitas teknis yang digunakan adalah kertas saring, kertas saring Whatman no. 1, Verile gel ${ }^{\circledR}$, metanol, pereaksi Mayer, pereaksi Dragendorff, Besi (III) klorida $\left(\mathrm{FeCl}_{3}\right)$ $5 \%$, ammonia $1 \%$, asam asetat anhidrida, larutan Kalium hidroksida $(\mathrm{KOH}) 5 \%$, larutan Natrium klorida $(\mathrm{NaCl}) 0,9 \%$, HPMC (Shadong Bio-Technology, Batch 226-0028), karbopol 934 (Shadong BioTechnology, Batch 1975-77468-688), TEA, propilen glikol (Shin-Etsu, Batch J 1055/12) dan metil paraben (Ueno Fine Chemicals Industry, Lot LA1010) akuabides dan akuades. Bahan kualitas pro analisis yang digunakan antara lain media Mueller-Hilton Agar (MHA), darah domba steril, Dimetil sulfoksida (DMSO), Magnesium (Mg), asam klorida $(\mathrm{HCl})$ pekat, asam sulfat $\left(\mathrm{H}_{2} \mathrm{SO}_{4}\right)$ pekat, kloroform $\left(\mathrm{CHCl}_{3}\right)$, larutan standar McFarland no 0,5.

\section{Bakteri Uji}

Bakteri uji yang digunakan pada penelitian ini adalah kultur murni bakteri Propionibacterium acnes dan
Staphylococcus epidermidis yang merupakan koleksi dari unit Laboratorium Mikrobiologi, Universitas Indonesia.

\section{Tahapan Penelitian}

\section{Sampel}

Sampel yang digunakan pada penelitian ini adalah daun pacar air yang diperoleh di Jl. Nirbaya, Kota Baru, Pontianak, Kalimantan Barat. Sampel yang diperoleh dideterminasi di Herbarium Bogoriense, Bidang Botani Pusat Penelitian Biologi-LIPI Bogor.

\section{Pengolahan Sampel}

Daun pacar air dipisahkan dari tangkai. Selanjutnya dibersihkan dari sisa-sisa tanah, kotoran dan dicuci dengan air mengalir. Sampel kemudian dikeringkan di dalam oven granul. Sampel yang telah kering dihaluskan dengan blender simplisia dan diayak dengan ayakan no. 40 mesh.

\section{Ekstraksi Sampel}

Simplisia ditimbang $10 \mathrm{~g}$ dan dibungkus dengan kertas saring. Sampel kemudian dimasukkan kedalam alat kelongsong dan diekstraksi dengan pelarut metanol pada suhu $70^{\circ} \mathrm{C}$. Proses sirkulasi secara kontinyu dihentikan sampai pelarut berwarna konstan atau bening. Ekstrak yang didapat dipekatkan menggunakan waterbath.

\section{Skrining Fitokimia}

Skrining fitokimia dilakukan terhadap ekstrak metanol daun pacar air meliputi pemeriksaan alkaloid, flavonoid, polifenol, tanin, triterpenoid, steroid, saponin dan kuinon.

\section{Uji Aktivitas Antibakteri Ekstrak}

Uji aktivitas antibakteri dari ekstrak metanol daun pacar air terhadap bakteri P.acnes dan S.epidermidis dilakukan dengan metode disc diffusion. Larutan ekstrak terdiri dari tiga variasi 
konsentrasi: $100 \mathrm{mg} / \mathrm{mL}$; $150 \mathrm{mg} / \mathrm{mL}$; dan $200 \mathrm{mg} / \mathrm{mL}$. Kontrol negatif yang digunakan adalah DMSO. Sebanyak 20 $\mu \mathrm{L}$ larutan ekstrak dan kontrol negatif dipipet ke kertas cakram. Kertas cakram kemudian diletakkan pada permukaan media Mueller-Hilton Agar (MHA) dengan 5\% darah kambing yang telah diinokulasikan bakteri $P$. acnes dan media MHA yang telah diinokulasikan bakteri S.epidermidis. Petri diinkubasi pada suhu $37^{\circ} \mathrm{C}$ selama 48 jam untuk bakteri P.acnes dan 24 jam untuk bakteri S.epidermidis. Pengujian dilakukan 3 kali pengulangan (Wayne, 2006).

Tabel 1. Formula Simplex Lattice Design

\begin{tabular}{cccc}
\hline Bahan & F1 & F2 & F3 \\
\hline Ekstrak & 20 & 20 & 20 \\
HPMC & 3,5 & 2 & 2,75 \\
Karbopol & 0,5 & 2 & 1,25 \\
TEA & 0,5 & 2 & 1,25 \\
Propilenglikol & 15 & 15 & 15 \\
Metil Paraben & 0,18 & 0,18 & 0,18 \\
Akuades ad & 100 & 100 & 100 \\
\hline
\end{tabular}

Keterangan :

F1: Formula dengan perbandingan basis HPMC:Karbopol (100:0)

F2: Formula dengan perbandingan basis HPMC:Karbopol (0:100)

F3: Formula dengan perbandingan basis HPMC:Karbopol (50:50)

\section{Formulasi Gel}

Sediaan gel yang dibuat terdiri dari 3 formula (Tabel 1). HPMC dikembangkan ke dalam air panas sebanyak 20 kali beratnya selama 15 menit. Setelah mengembang digerus sampai transparan. Carbopol pada lumpang yang berbeda dikembangkan dengan air panas hingga homogen, kemudian ditambahkan trietanolamin (TEA) hingga jernih. HPMC yang telah dikembangkan dimasukkan ke dalam lumpang yang berisi carbopol dan digerus hingga homogen. Metil paraben yang telah dilarutkan dalam propilenglikol dicampurkan ke dalam basis dan digerus hingga homogen. Akuadest ditambahkan sedikit demi sedikit dan digerus homogen hingga diperoleh dasar gel (Suardi, dkk., 2008). Kemudian ditambahkan ekstrak metanol daun pacar air digerus sampai homogen.

\section{Uji Efek Antijerawat Gel Formula Simplex Lattice Design}

Uji aktivitas antibakteri dari gel ekstrak metanol daun pacar air dilakukan dengan metode disc diffusion. Kertas cakram direndam dalam gel F1, F2, F3 dan kontrol negatif selama 3 menit. Kertas cakram kemudian diletakkan pada permukaan media Mueller-Hinton Agar (MHA) dengan 5\% darah domba pada petri yang telah diinokulasikan bakteri $P$. acnes dan media MHA yang telah diinokulasikan bakteri S.epidermidis. Petri dibiarkan pada suhu ruang selama 1 jam sebelum diinkubasi pada suhu $37^{\circ} \mathrm{C}$ selama 48 jam untuk bakteri P.acnes dan 24 jam untuk bakteri S.epidermidis. Pengujian dilakukan 3 kali pengulangan. Aktivitas antibakteri ditentukan dengan mengukur diameter zona hambat (Suardi, dkk., 2008).

\section{Penentuan Formula Optimum}

Setelah dilakukan uji efektivitas antibakteri gel formula 1, 2 dan 3, selanjutnya dilakukan pengolahan data untuk memperoleh formula optimum.

\section{Uji Efektivitas Sediaan Gel Optimum}

Formula optimum komposisi Karbopol dan HPMC yang ditentukan, kemudian diuji efektivitas. Pengujian dilakukan untuk membandingkan hasil percobaan dengan hasil prediksi. Gel optimum juga dilakukan uji efektivitas antibakteri yang akan dibandingkan dengan kontrol positif berupa Verile gel. Prosedur pengujian efektivitas pada formula gel optimum, dilakukan seperti pada pengujian aktivitas antibakteri terhadap gel ekstrak metanol daun pacar air. 


\section{Evaluasi Sediaan Optimum}

Evaluasi sediaan gel yang dilakukan meliputi pengamatan organoleptis, homogenitas, pengukuran $\mathrm{pH}$, pengukuran viskositas, pengujian daya sebar dan pengujian daya lekat.

\section{Pengamatan Organoleptis}

Pemeriksaan organoleptis yang dilakukan meliputi pemeriksaan bentuk, tekstur, warna dan bau yang diamati secara visual (Kumesan, dkk., 2013).

\section{Pengujian Homogenitas}

Pengujian homogenitas dilakukan dengan cara sampel gel dioleskan pada sekeping kaca atau bahan transparan lain yang cocok, sediaan harus menunjukkan susunan yang homogen dan tidak terlihat adanya butiran kasar (Kumesan, dkk., 2013).

\section{Pengukuran pH}

Pengukuran $\mathrm{pH}$ sediaan dilakukan dengan menggunakan $\mathrm{pH}$ meter soil tester. Alat $\mathrm{pH}$ meter dicelupkan secara langsung ke dalam sediaan gel. Kemudian dilihat perbahan skala pada $\mathrm{pH}$ meter. Angka yang tertera pada skala $\mathrm{pH}$ meter merupakan nilai $\mathrm{pH}$ dari sediaan.

\section{Pengukuran Viskositas}

Rotor yang digunakan terlebih dahulu dipasang pada alat. Sampel dimasukkan ke dalam wadah kemudian rotor dimasukkan sampai tercelup. Alat dihidupkan dan diukur viskositasnya dengan cara membaca langsung pada skala.

\section{Pengujian Daya Sebar}

Gel sebanyak $0,5 \mathrm{~g}$ diletakkan di tengah-tengah kaca bulat, ditutup dengan kaca lain yang telah ditimbang beratnya dan dibiarkan selama 1 menit kemudian diukur diameter sebar gel. Setelah itu ditambahkan beban $50 \mathrm{~g}$ dan dibiarkan 1 menit kemudian diukur diameter sebarnya. Penambahan beban berat setelah 1 menit dilakukan secara terus- menerus hingga diperoleh diameter yang cukup untuk melihat pengaruh beban terhadap perubahan diameter sebar gel (Michael dan Ash, 1977).

\section{Pengujian Daya Lekat}

Gel sebanyak $0,25 \mathrm{~g}$ diletakkan pada gelas obyek dan ditekan dengan beban $1 \mathrm{~kg}$ selama 5 menit. Setelah itu gelas obyek dipasang pada alat tes. Alat tes diberi beban $80 \mathrm{~g}$ dan kemudian dicatat waktu pelepasan gel dari gelas obyek (Michael dan Ash, 1977).

\section{Analisis Data}

Analisis data statistik dilakukan menggunakan uji statistik One Way ANOVA (Analysis of Varians) dan uji T.

\section{HASIL DAN PEMBAHASAN}

\section{Determinasi Sampel Tumbuhan}

Berdasarkan hasil identifikasi tanaman yang dilakukan di Herbarium Bogoriense, Bidang Botani Pusat Penelitian BiologiLIPI Bogor menyatakan bahwa tanaman yang digunakan pada penelitian ini adalah tanaman pacar air (Impatiens balsamina Linn.)

Tabel 2. Hasil Skrining Fitokimia

\begin{tabular}{|c|c|c|c|}
\hline No. & Pemeriksaan & Reagen & Hasil \\
\hline 1. & Alkaloid & $\begin{array}{c}\text { Mayer, } \\
\text { Dragendorf }\end{array}$ & - \\
\hline 2. & Flavonoid & $\begin{array}{l}\mathrm{Mg}+\mathrm{HCl} \\
\text { pekat }\end{array}$ & + \\
\hline 3. & Saponin & Akuades & - \\
\hline 4. & Tanin & Gelatin & - \\
\hline 5. & Triterpenoid & $\begin{array}{c}\text { Lieberman } \\
\text { Burchard }\end{array}$ & - \\
\hline 6. & Steroid & $\begin{array}{c}\text { Lieberman } \\
\text { Burchard }\end{array}$ & + \\
\hline 7. & Kuinon & KOH 5\% & + \\
\hline 8. & Polifenol & $\mathrm{FeCl}_{3}$ & + \\
\hline
\end{tabular}

\section{Skrining Fitokimia}

Hasil skrining fitokimia terhadap ekstrak metanol daun pacar air (tabel 2) menunjukkan ekstrak mengandung 
senyawa flavonoid, steroid, kuinon dan polifenol.

\section{Hasil Uji Aktivitas Antibakteri Ekstrak}

Uji aktivitas aktibakteri dilakukan dengan metode disc diffusion. Metode disc diffusion adalah metode untuk menentukan aktivitas suatu agen antimikroba. Kontrol negatif yang digunakan ialah larutan DMSO, karena DMSO digunakan sebagai pelarut ekstrak dan tidak memberikan aktivitas antibakteri (Vats dan Sharma, 2012). Larutan DMSO yang digunakan yaitu dengan variasi konsentrasi $10 \%$.

Hasil pengujian ekstrak (tabel 3), menunjukkan bahwa semakin besar konsentrasi uji maka diameter zona hambat yang dihasilkan semakin besar. Hal ini diduga karena ekstrak yang berdifusi kedalam sel bakteri semakin meningkat sebanding dengan konsentrasi. Hasil penelitian menunjukkan bahwa ekstrak metanol daun pacar air memiliki aktivitas antibakteri terhadap bakteri P.acnes dan S.epidermidis sebagai penyebab jerawat.

Tabel 3. Hasil Uji Aktivitas Ekstrak ( $\overline{\mathbf{x}} \pm$ $\mathrm{SD}, \mathrm{n}=3$ )

\begin{tabular}{ccc}
\hline Bakteri Uji & $\begin{array}{c}\text { Konsentrasi } \\
\text { ekstrak } \\
(\mathrm{mg} / \mathrm{mL})\end{array}$ & $\begin{array}{c}\text { Diameter Zona } \\
\text { Hambat }(\mathrm{mm})\end{array}$ \\
\hline \multirow{4}{*}{ P.acnes } & 100 & $8,11 \pm 0,35$ \\
& 150 & $8,58 \pm 0,34$ \\
& 200 & $11,66 \pm 1,08$ \\
& DMSO & - \\
\hline S. & 100 & $9,30 \pm 0,57$ \\
epidermidis & 150 & $12,01 \pm 1,07$ \\
& 200 & $15,20 \pm 0,37$ \\
& DMSO & - \\
\hline
\end{tabular}

Aktivitas antibakteri dari ekstrak metanol daun pacar air diduga karena adanya senyawa polifenol, flavonoid, steroid dan kuinon. Senyawa polifenol memiliki aktivitas antibakteri yaitu dengan menghambat aktivitas enzim, membentuk kompleks dengan dinding sel bakteri (Tiwari, dkk., 2011). Turunan senyawa flavonoid yaitu kaemferol dan kuersetin yang terkandung dalam tanaman pacar air memiliki aktivitas antibakteri (Lim Young-Hee, dkk., 2007). Mekanisme kerja antibakteri kuersetin yaitu dengan menghambat kerja DNAgyrase dari bakteri (Lim Young-Hee, dkk., 2007). Kuersetin juga dapat meningkatkan permeabilitas dari membran sel bakteri dan menghilangkan potensial membran sel bakteri sehingga sintesis ATP, transpor membran dan motilitas terganggu. Kaemferol diduga memiliki aktivitas yang sama dengan kuersetin karena memiliki struktur yang hampir sama dan juga memiliki konsentrasi hambat minimal yang sama dengan kuersetin terhadap bakteri $P$. acnes (Lim Young-Hee, dkk., 2007). Sedangkan senyawa naftokuinon yang memiliki aktivitas antibakteri ialah senyawa 2-hidroksi 1,4-naftokuinon, 2metoksi 1,4-naftokuinon dan metilen 3,3'-bilawsone. Naftokuinon memiliki aktivitas antibakteri yaitu dengan mekanisme mengikat asam amino nukleofilik dari protein secara irreversible sehingga menyebabkan inaktifasi dari protein dan kehilangan fungsi. Selain itu naftokuinon juga mengikat adhesin, polipeptida dari dinding sel dan enzim pada membran (Cowan, 1999).

Berdasarkan hasil analisa data diameter zona hambat dari ketiga konsentrasi ekstrak daun pacar air terhadap bakteri P.acnes menunjukkan data tidak berbeda signifikan $(\mathrm{p}<0,05)$. Sedangkan hasil analisa data diameter zona hambat dari ketiga konsentrasi ekstrak daun pacar air terhadap bakteri S.epidermidis menunjukkan adanya perbedaan yang signifikan $(p>0,05)$. Oleh karena itu, digunakan konsentrasi tertinggi dari ketiga konsentrasi uji yaitu $200 \mathrm{mg} / \mathrm{mL}$ yang digunakan pada formulasi untuk menghasilkan gel yang efektif terhadap kedua bakteri tersebut. 


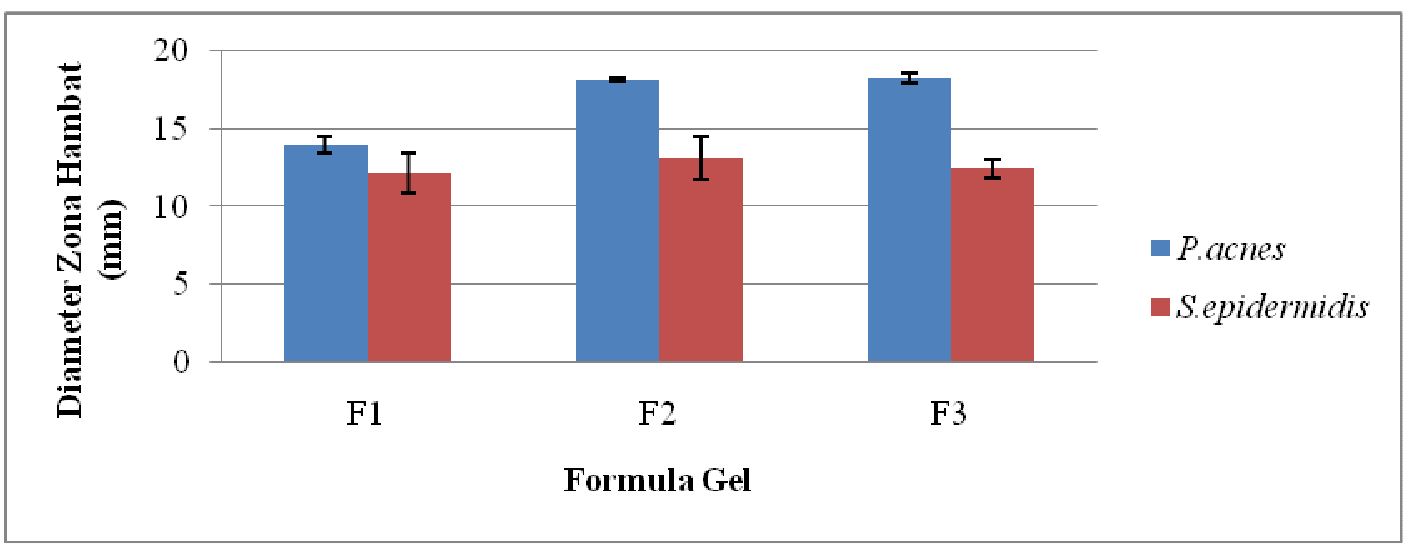

Gambar 1. Hasil Uji Efektivitas Gel Formula Simplex Lattice

\section{Hasil Uji Efek Antijerawat Gel Formula Simplex Lattice Design}

Gel yang dibuat dalam penelitian ini terdiri dari tiga formula yaitu F1 (HPMC:karbopol 100:0), F2 (HPMC:karbopol 0:100) dan F3 (HPMC:karbopol 50:50). Hasil pengujian efektivitas gel ekstrak metanol daun pacar air (Gambar 1) menunjukkan bahwa gel memiliki efektivitas antibakteri yang ditandai dengan adanya zona hambat berupa zona bening disekitar cakram. Diameter zona hambat yang paling besar terlihat pada F2 dan F3.

Formula tersebut terdiri dari HPMC dan karbopol masing-masing sebesar 0:100 dan 50:50. Karbopol memiliki pengaruh lebih besar dalam meningkatkan efektivitas antibakteri dibandingkan HPMC. Hal ini terlihat dari formula dengan komposisi karbopol yang lebih besar menghasilkan diameter zona hambat yang lebih besar pula. Karbopol memberikan interaksi positif terhadap efektivitas daya hambat. Jadi, kombinasi HPMC dan karbopol dengan jumlah komposisi karbopol lebih besar dapat meningkatkan efektivitas antibakteri, karena kombinasi dari kedua basis gel tersebut dapat meningkatkan difusi zat aktif (Quinones dan Ghaly, 2008). Zat aktif tersebut dapat berdifusi dari matriks gel ke dalam media agar sehingga dapat menghambat pertumbuhan bakteri yang berada di media agar tersebut.

\section{Penentuan Formula Optimum}

Optimasi dilakukan pada basis gel yang terdiri dari HPMC dan karbopol yang diatur dalam rentang dengan jumlah masing-masingnya untuk HPMC sebesar 0-1\% sedangkan karbopol sebesar 0-1\%. Respon diameter zona hambat pada bakteri P.acnes dan S.epidermidis dengan range $6 \mathrm{~mm}-20 \mathrm{~mm}$ dioptimumkan dengan target maximize dan importance $(+++++)$. Hal ini dikarenakan agar respon diameter zona hambat yang dihasilkan dapat lebih besar sehingga lebih efektif sebagai antibakteri, sehingga formula optimum dapat menghasilkan zona hambat yang lebih besar.

Formula optimum hasil prediksi terdiri dari HPMC 21\% dan karbopol $79 \%$ dengan nilai desirability sebesar 0,722 . Respon yang paling optimum diperoleh jika nilai desirability mendekati 1. Formula yang diprediksi tersebut dapat menghasilkan gel dengan perkiraan diameter zona hambat pada P.acnes sebesar 17,61 $\pm 0,93 \mathrm{~mm}$ dan diameter zona hambat pada S.epidermidis sebesar $16,01 \pm 1,01 \mathrm{~mm}$.

Kurva desirability gel optimum (Gambar 2) menunjukkan kecendrungan nilai desirability apabila terdiri dari komponen HPMC dan karbopol dalam jumlah tertentu. Titik prediksi tersebut menunjukkan kombinasi HPMC 21\% dan karbopol $79 \%$ menghasilkan nilai desirability yang jauh lebih besar dibandingkan dengan kombinasi HPMC:karbopol 50:50. Sehingga dapat 
diprediksikan bahwa kombinasi HPMC $21 \%$ dan karbopol $79 \%$ adalah formula optimum.

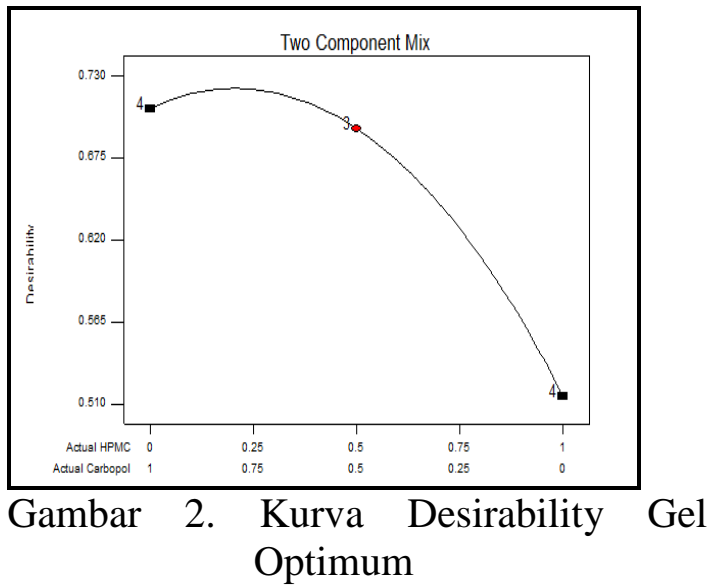

\section{Uji Efektivitas Gel Optimum}

Hasil percobaan (tabel 4) untuk respon diameter zona hambat pada P.acnes dan S.epidermidis berada dalam rentang nilai prediksi berdasarkan metode simplex lattice design. Definisi 95\% PI (Prediction Interval) rendah adalah nilai terendah dari interval yang diprediksikan, dimana memiliki nilai kepercayaan dari pengamatan individual sebesar $95 \%$. Sedangkan definisi 95\% PI (Prediction Interval) tinggi adalah nilai tertinggi dari interval yang diprediksikan, dimana memiliki nilai kepercayaan dari pengamatan individual sebesar $95 \%$.

Tabel 4. Hasil Uji Efektivitas Gel Optimum $(\overline{\mathbf{x}} \pm \mathrm{SD}, \mathrm{n}=3)$

\begin{tabular}{cccc}
\hline \multirow{2}{*}{ Bakteri Uji } & Hasil Uji & \multicolumn{2}{c}{$95 \%$ PI } \\
\cline { 3 - 4 }$(\mathrm{mm})$ & low & high \\
\hline P.acnes & $17,61 \pm 0,93$ & 17,55 & 19,98 \\
\hline $\begin{array}{c}S . \\
\text { epidermidis }\end{array}$ & $16,01 \pm 1,01$ & 9,53 & 16,17 \\
\hline
\end{tabular}

Kesimpulan yang diperoleh adalah metode simplex lattice design dapat digunakan untuk memprediksi formula optimum gel ekstrak metanol daun pacar air (Impatiens balsamina Linn.) terhadap bakteri P.acnes dan S.epidermidis.
Hasil uji efektivitas gel optimum terhadap kontrol positif (tabel 5) menunjukkan bahwa gel optimum menghasilkan diameter zona hambat lebih kecil dibandingkan dengan kontrol positif yaitu Verile gel.

Tabel 5. Hasil Uji Efektivitas Gel Optimum Terhadap Kontrol Positif $(\overline{\mathbf{x}} \pm \mathrm{SD}, \mathrm{n}=3)$

Diameter

\begin{tabular}{ccc} 
Bakteri Uji & Sampel & $\begin{array}{c}\text { Zona Hambat } \\
(\mathrm{mm})\end{array}$ \\
\hline P.acnes & Gel Optimum & $17,61 \pm 0,93$ \\
& Kontrol positif & $29,1 \pm 1,34$ \\
\hline S. & Gel Optimum & $16,01 \pm 1,01$ \\
epidermidis & Kontrol Positif & $24,98 \pm 1,83$ \\
\hline
\end{tabular}

Berdasarkan hasil uji $\mathrm{t}$ didapatkan nilai signifikansi $\mathrm{p}<0,05$ untuk rata-rata diameter zona hambat P.acnes terhadap Verile gel, sedangkan rata-rata diameter zona hambat S.epidermidis terhadap Verile gel didapat nilai signifikansi $\mathrm{p}<0,05$. Berdasarkan analisa statistik terdapat perbedaan signifikan efektivitas antibakteri antara gel optimum dengan kontrol positif. Hal ini menunjukkan bahwa gel optimum ekstrak metanol daun pacar air memiliki potensi untuk pengembangan lebih lanjut agar menghasilkan efektivitas antibakteri yang lebih baik.

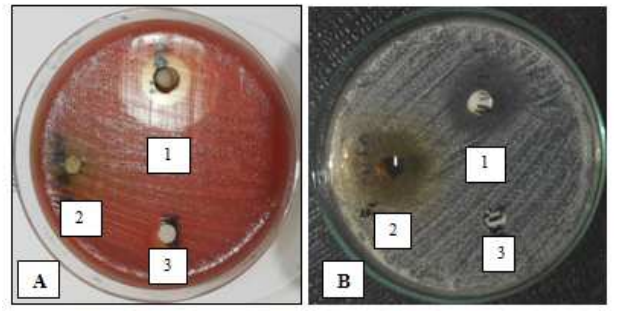

Gambar 3. Hasil Uji Efektivitas Gel Optimum Terhadap Kontrol Positif: (A) Bakteri P.acnes; (B) Bakteri S.epidermidis; 1. Kontrol Positif; 2. Gel Optimum; 3. Kontrol Negatif 


\section{Hasil Evaluasi Sediaan Gel Optimum}

Hasil organoleptis gel optimum yang dibuat berupa gel berwarna coklat tua yang memiliki bau khas ekstrak dengan bentuk yang kurang kental. Hal ini dikarenakan jumlah ekstrak yang digunakan $20 \%$ dalam sediaan sehingga mempengaruhi bau, penampilan serta bentuk dari sediaan gel tersebut. Hasil pemeriksaan homogenitas menunjukkan bahwa sediaan gel memperlihatkan adanya butir-butir kasar pada saat sediaan dioleskan pada kaca transparan. Hal ini dikarenakan masih terdapat ekstrak yang tidak tercampur pada basis gel.

Pengukuran viskositas bertujuan untuk mengetahui seberapa besar konsistensi dari sediaan gel optimum. Viskositas berkaitan dengan kemampuan sediaan untuk dapat mengalir yang akan mempengaruhi daya sebar dan daya lekat, serta mempengaruhi difusi obat (Hasyim, dkk., 2012). Nilai rata-rata viskositas pada gel optimum sebesar 426,66 cP. Hal ini menunjukkan bahwa gel optimum memiliki viskositas yang rendah. Pengukuran daya lekat bertujuan untuk mengetahui kemampuan suatu sediaan untuk bertahan pada permukaan kulit yang berkaitan dengan difusi obat pada permukaan kulit. Nilai rata-rata daya lekat gel optimum adalah 178,66 detik. Hal ini menunjukkan bahwa gel optimum tidak bertahan lama pada kulit. Pengukuran daya sebar pada gel optimum bertujuan untuk mengetahui kemampuan menyebar sediaan ketika digunakan. Nilai rata-rata daya sebar gel optimum sebesar $32,69 \mathrm{~cm}^{2}$. Hal ini menunjukkan bahwa gel optimum memiliki daya sebar yang luas sehingga mudah untuk dioleskan pada permukaan kulit. Sedangkan pengukuran $\mathrm{pH}$ bertujuan untuk mengetahui keamanan sediaan. Nilai $\mathrm{pH}$ yang terlalu rendah dapat menyebabkan iritasi, sedangkan $\mathrm{pH}$ terlalu tinggi dapat menyebabkan kulit bersisik. Nilai ratarata $\mathrm{pH}$ gel optimum sebesar 5,23. Berdasarkan Standar Nasional Indonesia rentang $\mathrm{pH}$ sediaan topikal adalah 4,5-8.
Hal ini menunjukkan bahwa nilai $\mathrm{pH}$ sediaan gel optimum masih berada pada rentang yang diperbolehkan.

Penelitian ini menunjukkan hasil bahwa adanya aktivitas antibakteri ekstrak metanol daun pacar air dan efektivitas gel ekstrak metanol daun pacar air. Peningkatan daya hambat terjadi pada ekstrak metanol daun pacar air dalam bentuk sediaan gel dibandingkan dengan ekstrak sebelum diformulasikan kedalam bentuk gel. Peningkatan efektivitas tersebut dikarenakan adanya bantuan basis gel yaitu HPMC dan karbopol. Kombinasi dari kedua basis gel dapat meningkatkan difusi zat aktif (Lim Young-Hee, dkk., 2007). Zat aktif tersebut dapat berdifusi dari gel ke dalam media agar sehingga dapat menghambat pertumbuhan bakteri yang berada di media agar tersebut.

\section{KESIMPULAN}

Komposisi optimum dari Karbopol dan HPMC dalam gel ekstrak metanol daun daun pacar air (Impatiens balsamina L.) yang memberikan efek antibakteri terbaik adalah HPMC 21\% dan carbopol $79 \%$. Hasil evaluasi gel optimum yaitu gel berwarna coklat tua, berbau khas ekstrak dengan nilai daya lekat 3,17 menit, daya sebar $32,69 \mathrm{~cm}^{2}$, viskositas sebesar 426,66 cP dan $\mathrm{pH}$ 5,23.

\section{DAFTAR PUSTAKA}

1. Adfa M. Senyawa Antibakteri Dari Daun Pacar Air (Impatiens Balsamina L). Jurnal Gradien. Desember 2007; 4(1): 318-322.

2. Bakker P, Grooskens Van D, Wieringa N. Dermatological Preparation for The Tropics. Den Haag : Cip Gegeveres koninklijke Bibliotheek; 1990.

3. Baviskar DT, Yogeshkumar AB, Kapil RB, Venkatesh BP, Mangesh KS dan Dinesh KJ. In Vitro and In Vivo Evaluation of Diclofenac Sodium Gel Prepared with Cellulose 
Ether and Carbopol 934P. Trop $J$ Pharm Res. 2013; 12(4): 489-494.

4. Clinical and Laboratory Standards Institute. Performance standards for antimicrobial disk susceptibility tests. Approved standard M2-A9. CLSI, Wayne, PA. 2006.

5. Cowan MM. Plant Products as Antimicrobial Agents. Clin Microbiol Rev. 1999; 12 (4): 564-582.

6. Dalimartha, S. Atlas Tumbuhan Obat Indonesia. Jilid 3. Jakarta : Trubus Agriwidya; 2003. Hal 85-88.

7. Hasyim N, Kristian LP, Iradah J, Ajeng K. Formulasi dan Uji Efektivitas Gel Luka Bakar Ekstrak Daun Cocor Bebek (Kalanchoe pinata L) pada Kelinci (Oryctolagus cuniculus). Majalah Farmasi dan Farmakologi. Juli 2012. 16(2); 89-94.

8. Suardi M, Armenia, Anita Maryawati. Formulasi dan Uji Klinik Gel Anti Jerawat Benzoil Peroksida-HPMC. Jurnal Fakultas Farmasi FMIPA UNAND. 2008.

9. Knutsen-Larson Siri, Annelise L. Dawson, Cory A. Dunnick, dan Robert P. Dellavalle. Acne Vulgaris: Pathogenesis, Treatment, and Needs Assessment. Dermatol Clin. 2012; 30:99-106.

10. Kumesan YAN, Yamlean PVY, dan Supriati. Formulasi dan Uji Aktivitas Gel Antijerawat Ekstrak Umbi Bakung (Crinum asiaticum L.) Terhadap Bakteri Staphylococcus aureus Secara In Vitro. Pharmacon. Mei 2013; 2(2): 18-26.
11. Lim Young-Hee, In Hwan Kim, Jungju Seo. In vitro Activity of Kaemferol Isolated from the Impatiens balsamina alone and in combination with Erythromycin or Clindamycin against Propionibacterium acnes. $J$ Microbiol. 2007; 45(5);473-477

12. Michael and Ash I. A Formulary of Cosmetic Preparation. Chemical Publishing Co., New York. 1977

13. Quinones D dan Ghaly E.S. Formulation and Characterization of Nystatin Gel. P R Health Sci J. 2008; 27(1): 61-67.

14. Russel JJ. Topical Therapy for Acne. Am Fam Physichian. 2000; 15(2) : 357-365.

15. Tasoula Eleni, S. Gregoriou, John Chalikias, Dimitris Lazarou, Ifigenia Danopoulou, Andreas Katsambas, dan Dimitris Rigopoulos. The impact of acne vulgaris on quality of life and psychic health in young adolescents in Greece. Results of a population survey. An Bras Dermatol. 2012; 87(6):862-9.

16. Tiwari P, Kumar B, Kaur M, Kaur G, Kaur H. Phytochemical Screening and Extraction : A Review. Int Pharm Sci. 2011; 1(1): 98-106.

17. Vats A, Sharma P. Formulation and Evaluation of Topical Anti Acne Formulation of Coriander Oil. Inter. J. Pharm. Sci. Res. 2012; 2(3): 61-66.

18. Wasitaatmadja S.M. Penuntun Ilmu Kosmetik Medik. Jakarta: UI-Press; 2002. Hal 182-188.

19. Webster G. F. Acne Vulgaris. Brit. Med. J. 2002; 325(7362):475-479. ISSN : 0019-5154. 